\title{
総合論文*
}

\section{発色団を有するポリチアザアルカン誘導体を用いる金属 イオンのセンシングと分離}

\author{
石川 淳一 ${ }^{* *}$, 坂本 英文 ${ }^{\circledR * * *}$, 和田 弘子 ${ }^{* *}$, 小友 允 $^{* *}$ \\ Metal ion sensing and separation using chromogenic \\ polythiazaalkane derivatives
}

\author{
Junichi IshikaWA $^{* *}$, Hidefumi Sakamoto ${ }^{* * *}$, Hiroko WadA and Makoto OTOMo ${ }^{* *}$ \\ ${ }^{* *}$ Department of Applied Chemistry, Nagoya Institute of Technology, Gokiso-cho, Showa-ku, Nagoya \\ 466-0061 \\ ${ }^{* * *}$ Department of Applied Chemistry, Faculty of Systems Engineering, Wakayama University, 930, \\ Sakaedani, Wakayama 640-8510
}

(Received 24 June 1998, Accepted 11 August 1998)

\begin{abstract}
Acyclic and cyclic dithiaza- and tetrathiazaalkane derivatives bearing the 6-trifluoromethyl-2,4-dinitrophenylhydrazono moiety as a chromogenic group on the nitrogen atom of the alkanes were synthesized and studied as complexing chromogenic reagents for a particular metal ion. In order to evaluate the metal ion recognition properties of these compounds, the following behaviors were examined: proton dissociation, metal ion complexation, metal ion extraction, and metal ion transport through a liquid membrane containing the compound. First, all of the hydrazone derivatives exhibited a similar proton dissociation constants and a silver ion selective complexation behavior in a 1,4dioxane-water solution. The blue shifts of the absorption spectra were caused by complexation of the hydrazone derivatives with silver ion. The complexing ability is mainly dependent on the number of sulfur atoms in the molecule. Secondly, tetrathiazaalkane hydrazone derivatives exhibited high selectivity for silver ion in the solvent extraction of some heavy metal ions. Drastic red shifts of the absorption spectra of the organic phase were observed in the extraction of silver ion with tetrathiazaalkane hydrazone derivatives. Acyclic tetrathiazaalkane hydrazone derivative extracted silver ion most efficiently. Thirdly, tetrathiazaalkane hydrazone derivatives exhibited effective uphill silver ion transport ability. Especially, a rapid and selective transport of silver ion was observed for an acyclic tetrathiazaalkane analog through liquid membranes.
\end{abstract}

Keywords : chromoionophore; polythiazaalkane; silver ion; complexation; solvent extraction; liquid membrane transport.

* 中部支部創立 40 周年記念

** 名古屋工業大学工学部応用化学科: 466-8555 愛知 県名古屋市中区御器所町

*** 和歌山大学システム工学部精密物質学科: 640-8510 和歌山県和歌山市栄谷 930
1 緒言

多種類の金属イオン中から特定の金属イオンを分離・ 定量するイオノホアの開発は分析化学の分野のみならず 
生化学や環境化学の分野においても重要な課題の一つで ある。これまで特定のアルカリ金属イオンを認識するイ オノホアとしてクラウンエーテル ${ }^{1) ~ 3)}$ が知られている. このクラウンエーテルは金属イオンと相互作用する際, 酸素原子と金属イオンとの親和力の程度とともに, クラ ウンエーテルの空孔径と金属イオン径とのフィッテング の程度が金属イオン錯形性能に大きく影響する ${ }^{4) \sim 6)}$. 一 方，環内のドナー原子として窒素原子を有するアザクラ ウンエーテルや硫黄原子を有するチアクラウンエーテル の金属イオン錯形成能は，そのドナー原子と高い親和力 を示す遷移金属イオンに移行する ${ }^{4) ~ 8)}$. しかし, 同一分 子内にドナー原子として硫黄原子と窒素原子を持つイオ ノホアの研究は，今までにない錯形成挙動が予測される のにもかかわらず，ほとんど行われていない.

一方，このようなイオノホアに発色団を導入すること で，イオノホアと金属イオンとの相互作用の程度を分光 光度法により評価することが可能となる. 特にプロトン 解離性の発色団を導入した場合, 溶媒抽出実験の際に陰 イオンを用いることなく, 相互作用し得る金属イオンを 有機相へ抽出できるばかりでなく, 有機相中のスペクト ル変化による金属イオンの定量 ${ }^{9 ; \sim 11)}$, この化合物を キャリヤーとした液膜輸送による金属イオン分離 ${ }^{12}$ が期 待される.

そこで本研究では新規な機能性を備えた比色試薬の開 発を目指して，ドナー原子として硫黄原子と窒素原子を 含む環状及び非環状のポリチアザアルカン誘導体に，プ ロトン解離型発色団である 2,4-ジニトロ-6-トリフルオロ メチルフェニルヒドラゾン部を導入した誘導体（Fig. 1) を合成した，そしてこれらヒドラゾン誘導体を用いて， （1）ジオキサン-水混合溶液中における酸解離及び金属 イオン錯形成挙動;（2）液液抽出系における金属イオン の溶媒抽出挙動; (3) バルク液体膜系に扔ける金属イオ ンのプロトン駆動型液膜輸送, について検討した.

\section{2 実験}

\section{$2 \cdot 1$ ヒドラゾン誘導体の合成}

本研究で使用しヒドラゾン誘導体は, 第一に $N, N$-ビ ス（2-ヒドロキシエチル)アニリンを原料として，これを 八ロゲン化及びトシル化した後にそれぞれ対応するチオ ール誘導体と反応させて無置換のNフェニルポリチア ザアルカン誘導体を得た ${ }^{13)}$. そしてこれをホルミル化し た後に，2,4ジニトロ-6-トリフルオロメチルフェニルヒ ドラジンと反応させてヒドラゾン誘導体を得た ${ }^{14)}$.

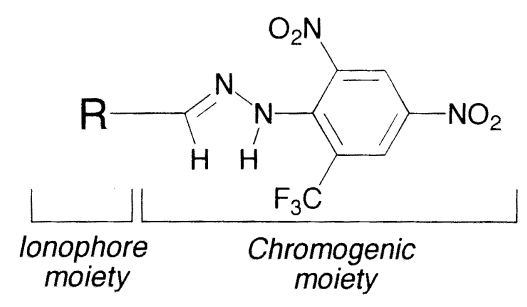

$\mathrm{R}$

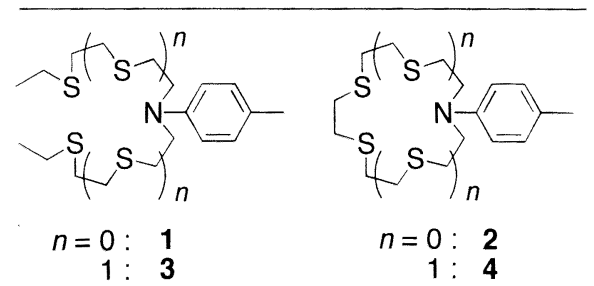

Fig. 1 Structure formulas of polythiazaalkane hydrazone derivatives

\section{$2 \cdot 2$ 測定操作}

$2 \cdot 2 \cdot 1$ ヒドラゾン誘導体の酸解離と金属イオン錯形 成特性一連のヒドラゾン誘導体は水に溶解しないた め, ヒドラゾン誘導体 $1 ， 3 ， 4$ とヒドラゾン誘導体 2 に対し，それぞれジオキサン $48(\mathrm{v} / \mathrm{v}) \%$ と $60(\mathrm{v} / \mathrm{v}) \%$ 水 溶液を使用した。いずれの場合も試薬濃度は $2 \times 10^{-5}$ M とした。硝酸, グッドバッファー, 水酸化カリウム により $\mathrm{pH}$ を, そして硝酸カリウムによりイオン強度を 0.2 に調製した。 ヒドラゾン誘導体の酸解離平衡を検討 する場合, 各々の $\mathrm{pH} に お け る$ 水溶液の吸収スペクトル を測定し, $\mathrm{pH}$ 变化に対する吸光度変化から直接探索法 により酸解離定数を算出した。一連のヒドラゾン誘導体 の金属イオン錯形成平衡を検討する場合, $\mathrm{pH}$ を一定に した水溶液の各金属イオンについて吸収スペクトルを測 定し, 金属イオン濃度変化に対する吸光度变化から直接 探索法により安定度定数を算出した。

\section{$2 \cdot 2 \cdot 2$ ヒドラゾン誘導体の金属イオン抽出挙動}

ヒドラゾン誘導体の金属イオン溶媒抽出を検討する場 合, 水相は硫酸, グッドバッファー, 水酸化カリウムに より $\mathrm{pH}$ を, 硫酸カリウムによりイオン強度を 0.2 に調 製した水溶液 $12 \mathrm{ml}$, 有機相はヒドラゾン誘導体を含む 1,2-ジクロロエタン溶液 $12 \mathrm{ml}$ を使用した。これらを 50 $\mathrm{ml}$ 遠沈管中で $25^{\circ} \mathrm{C}$ で 1 時間振り混ぜ, 静置した後に有 機相中の吸光度を測定した。 又, 必要に応じて水相の金 属イオン濃度を原子吸光法により測定した. ヒドラゾン 誘導体の金属イオン選択性を検討する場合, 金属イオン 
$1 \times 10^{-3} \mathrm{M}$ を含み, $\mathrm{pH}$ を 6 に調整した水相と, ヒドラ ゾン誘導体 $2 \times 10^{-5} \mathrm{M}$ を含む有機相を使用した金属イ オン過剩の条件と，金属イオン $1 \times 10^{-5} \mathrm{M}$ を含み, $\mathrm{pH}$ を 6 に調整した水相と, ヒドラゾン誘導体 $1 \times 10^{-4} \mathrm{M}$ を含む有機相を使用した試薬濃度過剩の条件の 2 種類 を行った. ヒドラゾン誘導体の銀イオン抽出平衡を検討 する場合, 銀イオンと試薬の濃度を一定にし, 各 $\mathrm{pH} に$ 対する水溶液の吸収スペクトルを測定し, $\mathrm{pH}$ 変化に対 する吸光度変化から直接探索法により抽出定数を算出し た.

\section{$2 \cdot 2 \cdot 3$ ヒドラゾン誘導体による銀イオンのプロトン} 駆動型液膜輸送液膜輸送装置は直径 $3 \mathrm{~cm}$, 高さ 12 $\mathrm{cm}$ の植物培養試験管のガラス容器の底面から高さ $1 \mathrm{~cm}$ のところに合わせて, 直径 $2 \mathrm{~cm}$ のパイレックスガラス 管を支持させた二重構造のセルを用いた 膜相として $2.5 \times 10^{-4} \mathrm{M}$ のヒドラゾン誘導体を含む 1,2ジクロロエタン溶液 $15 \mathrm{ml}$, ガラス管の内側に供給相,

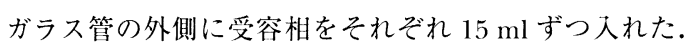
そして底部の液膜相のみを長さ $2.5 \mathrm{~cm}$ のかくはん子で $200 \mathrm{rpm}$ でかくはんした，銀イオン液膜輸送実験は，供 給相の銀イオン濃度がキャリヤー濃度と等濃度である $2.5 \times 10^{-4} \mathrm{M}$ の場合とキャリヤー濃度より過剩である $5 \times 10^{-3} \mathrm{M}$ の場合について行った.

\section{3 結果と考察}

\section{$3 \cdot 1$ ヒドラゾン誘導体の酸解離及び金属イオン錯形 成挙動 ${ }^{14)}$}

本研究で合成したヒドラゾン誘導体の基礎的特性を調 ベるために，ジオキサンー水混合溶液系におけるヒドラ ゾン誘導体の酸解離挙動と金属イオン錯形成挙動につい て検討した。

$3 \cdot 1 \cdot 1$ ヒドラゾン誘導体の酸解離平衡 一連のヒ ドラゾン誘導体のイミノ基水素の酸解離特性について検 討した. Fig. 2 にヒドラゾン誘導体 3 の $\mathrm{pH}$ 変化に対す る吸収スペクトル変化を示す. $440 \mathrm{~nm}$ 付近に吸収極大
を持つプロトン非解離の試薬の吸収スペクトルは, $\mathrm{pH}$ の増加によるイミノ基窒素のプロトン解離に伴って 520 $\mathrm{nm}$ 付近に吸収スペクトルが長波長シフトすることを認 めた。この吸光度変化の $\mathrm{pH}$ 依存性から酸解離定数を算 出した. それぞれのヒドラゾン誘導体の酸解離定数とそ の吸収特性を Table 1 に示す。この表から酸解離定数 の值と吸収特性は化合物間で大きな違いは見られないこ とが分かる.このことから，一連のヒドラゾン誘導体の 分光学的特性と酸解離特性は錯形成部であるポリチアザ アルカン部分の長さや立体構造に依存しないことを認め た.

$3 \cdot 1 \cdot 2$ 金属イオン錯形成挙動 次にヒドラゾン誘 導体が酸解離しない $\mathrm{pH}$ 領域で, ヒドラゾン誘導体を中 性配位子として使用した場合の数種の金属イオンとの錯 形成挙動について検討した。 ヒドラゾン誘導体 $\mathbf{3}$ の銀 イオン添加による吸収スペクトル変化を Fig. 3 に示す. これから，添加した銀イオン濃度の増加とともに 440

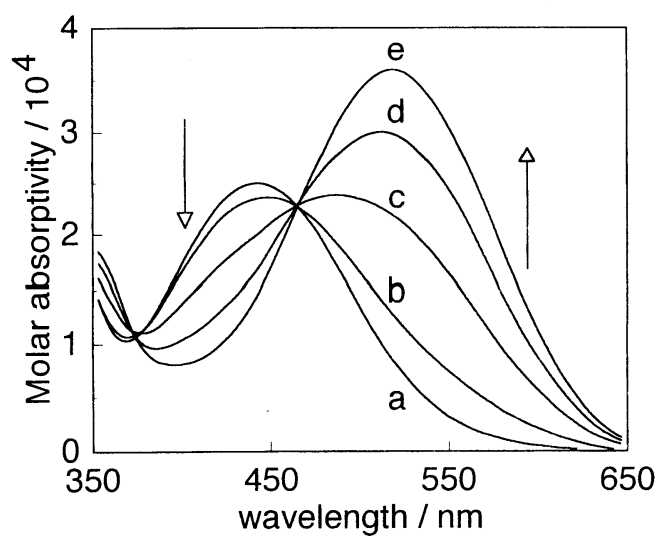

Fig. 2 pH-dependent spectral change of hydrazone 3 in 1,4-dioxane-water $(48 / 52(\mathrm{v} / \mathrm{v}) \%)$ [ligand] $=2 \times 10^{-5} \mathrm{M} ; \mathrm{pH}=$ a) 4.36 , b) 6.98 , c) 7.82 , d) 8.44 , e) 9.23

Table 1 Proton dissociation constants $\left(K_{\mathrm{a}}\right)$ and molar absorptivities $(\varepsilon)^{\mathrm{a})}$ of hydrazone derivatives in 1,4-dioxanewater solution

\begin{tabular}{cccc}
\hline Compound & $\mathrm{p} K_{\mathrm{a}}^{\mathrm{b})}$ & $\mathcal{E}_{\mathrm{HL}} / 10^{4}\left(\mathrm{at} \lambda_{\max } / \mathrm{nm}\right)$ & $\varepsilon_{\mathrm{L} .} / 10^{4}\left(\mathrm{at} \lambda_{\max } / \mathrm{nm}\right)$ \\
\hline $\mathbf{1}^{\mathrm{c})}$ & 8.03 & $2.66(446)$ & $4.03(519)$ \\
$\mathbf{2}^{\mathrm{d})}$ & 8.19 & $2.63(443)$ & $3.95(517)$ \\
$\mathbf{3}^{\mathrm{c})}$ & 8.05 & $2.52(441)$ & $3.80(519)$ \\
$\mathbf{4}^{\mathrm{c})}$ & 8.06 & $2.57(444)$ & $3.83(517)$ \\
\hline
\end{tabular}

a) Errors for values of $\varepsilon$ were less than $\pm 300 \mathrm{~mol}^{-1} \mathrm{dm}^{3} \mathrm{~cm}^{-1}$, b) $\mathrm{p} K_{\mathrm{a}}=-\log K_{\mathrm{a}}$, errors for values of $\mathrm{p} K_{\mathrm{a}}$ were within $\pm 0.02, \mathrm{c})$ In 1,4-dioxane-water $(48 / 52(\mathrm{v} / \mathrm{v}) \%)$, d) In 1,4-dioxane-water $(60 / 40(\mathrm{v} / \mathrm{v}) \%)$. 
$\mathrm{nm}$ 付近に吸収極大を持つ遊離の吸収スペクトルは, 銀 イオン錯形成に伴って吸収極大波長が $400 \mathrm{~nm}$ 付近に短 波長シフトすることを認めた。このような吸収スペクト ルの短波長シフトは金属イオンと錯形成する際に, 錯化 した金属イオンとポリチアザアルカン部分の窒素原子の 非共有電子対とが相互作用することにより，発色団であ るヒドラゾン部分の電子密度が低下するためと考えられ る. 例として, ヒドラゾン誘導体 3 の酸解離及び銀イ オン錯形成機構を Fig. 4 にまとめる.このような金属 イオン錯形成に基づくスペクトル変化はドナーーアクセ プター型の発色性イオノホアで見られる ${ }^{16) ~ 20)}$. 添加し た銀イオン濃度変化に対するヒドラゾン誘導体の吸光度 変化を Fig. 5 に示す. この吸光度変化から金属イオン 錯体の安定度定数を算出した. それぞれのヒドラゾン誘

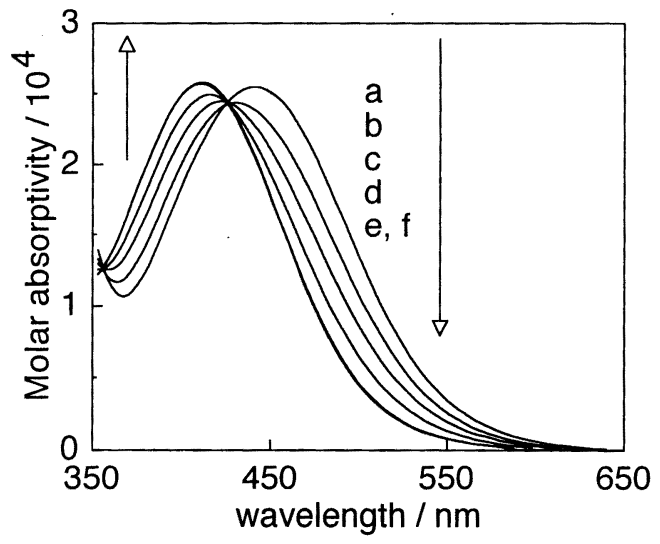

Fig. 3 Silver ion-concentration dependent spectral change of hydrazone 3 in 1,4-dioxane-water (48/52 (v/v) \%)

[ligand] $=2 \times 10^{-5} \mathrm{M}$; [Silver ion] = a) 0 , b) $0.5 \times$ $10^{-5}$, c) $1.0 \times 10^{-5}$, d) $1.5 \times 10^{-5}$, e) $2.0 \times 10^{-5}$, f) $2.5 \times 10^{-5} \mathrm{M}$
導体の金属イオン安定度定数とその吸収特性を Table 2 に示す．又，Fig. 5 中には安定度定数から算出した計算 曲線を併せて示している，この表から，いずれのヒドラ ゾン誘導体も銀イオンとほぼ選択的に錯形成することが 分かる.この銀イオン選択性はチアクラウンエーテル誘 導体においても報告されている22123). これは錯形成部で あるポリチアザアルカン部分の硫黄原子がソフトな塩基 として働くためにソフトな酸であるクラス b に属する 銀イオンと選択的に錯形成するものと考えられる．特に

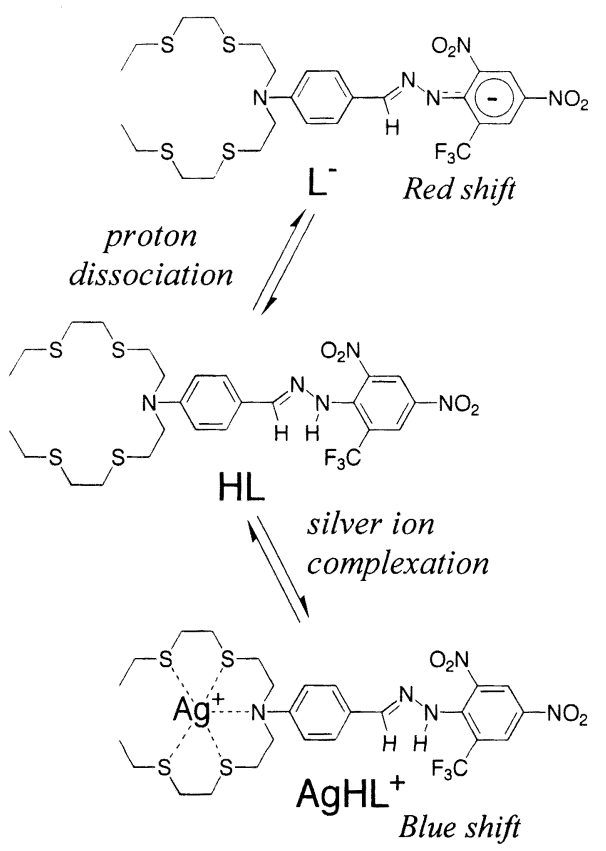

Fig. 4 Postulated structures of hydrazone 3 for proton dissociation and silver ion complexation in 1,4-dioxane

Table 2 Stability constants $\left(K_{\mathrm{MHL}}\right)^{\text {a) }}$ of complexes of dithiaza- and tetrathiazaalkane hydrazones, $1 \sim 4$, with heavy metal ions

\begin{tabular}{|c|c|c|c|c|c|c|c|}
\hline \multirow{2}{*}{ Compound } & \multicolumn{7}{|c|}{ Stability constant $\left(\log K_{\mathrm{MHL}}\right)$} \\
\hline & $\mathrm{Ni}^{2+}$ & $\mathrm{Cu}^{2+}$ & $\mathrm{Zn}^{2+}$ & $\mathrm{Cd}^{2+}$ & $\mathrm{Pb}^{2+}$ & $\mathrm{Tl}^{+}$ & $\mathrm{Ag}^{+}$ \\
\hline 1 & & -b) & - b) $^{\text {b }}$ & & -b) & & 4.6 \\
\hline 2 & & $-{ }^{b)}$ & $-{ }^{b)}$ & & 一 $^{\mathrm{b})}$ & & 4.8 \\
\hline 3 & 0.5 & 3.3 & $-{ }^{b)}$ & - b) & $-^{\mathrm{b})}$ & - $^{\mathrm{b})}$ & $>7^{\mathrm{c})}$ \\
\hline 4 & & 3.2 & - $^{\text {b) }}$ & & $-{ }^{b)}$ & & $>7^{\mathrm{c})}$ \\
\hline
\end{tabular}

a) Errors for values of $\log K_{\mathrm{MHL}}$ were within \pm 0.1 . $\quad$ b) The value of $\log K_{\mathrm{MHL}}$ was less than 0.1 . c) The value of $K_{\mathrm{MHL}}$ was more than that of determination limit. 
ポリチアザアルカン部分に硫黄原子を 4 個有するヒド ラゾン誘導体 3 と 4 は, 添加した銀イオンに対して定 量的に反応したため，その安定度定数を算出することが できなかった。又，錯形成部に硫黄原子を 2 個有する ヒドラゾン誘導体 1,2 そその非環状 - 環状の基本構造 の違いにかかわらず，同程度の銀イオン選択性と錯形成 能を示した。このように, 一連のヒドラゾン誘導体の銀 イオン錯形成能はポリチアザアルカン部分の環状・非環 状の構造的な要因よりはその硫黄原子の数に依存するこ とを見いだした，又， Table 3 に銀イオン錯体 $\left(\mathrm{AgHL}^{+}\right)$ の酸解離定数 $\left(\mathrm{AgHL}^{+} \rightleftharpoons \mathrm{H}^{+}+\mathrm{AgL}\right)$ と銀イオン錯体 $\left(\mathrm{AgHL}^{+}, \mathrm{AgL}\right)$ の吸収特性をまとめた. Table 1 との 比較により，特にヒドラゾン誘導体 $1,3,4$ では銀イ オン錯形成に基づくイミノ基水素の酸解離の促進と, $\mathrm{HL}$ と $\mathrm{L}^{-}$に対するそれぞれ $\mathrm{AgHL}^{+}$と $\mathrm{AgL}$ の吸収極大

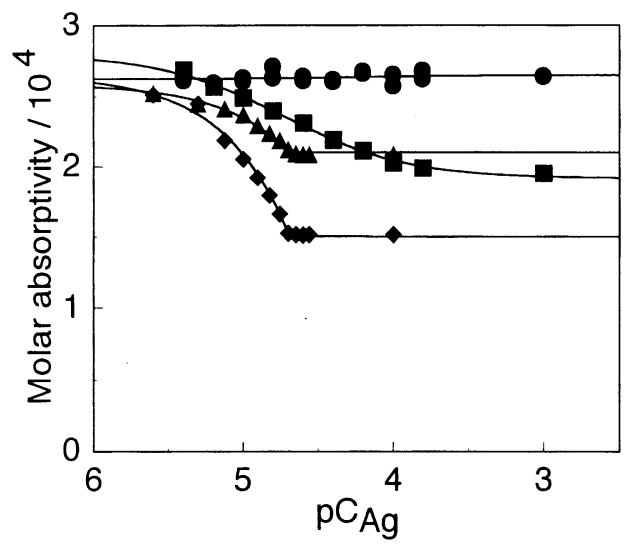

Fig. 5 Plots of molar absorptivity at maximum wavelength of free ligand $v s-\mathrm{pC}_{\mathrm{Ag}}$ on the complexation of hydrazone derivative with silver ion in 1, 4dioxane-water

$\mathbf{1} ;(\mathbf{\square}): \mathbf{2} ;(\boldsymbol{O}): \mathbf{3} ;(\boldsymbol{\Delta}): \mathbf{4} ;(\boldsymbol{)})$ : Initial concentration: [ligand] $=2 \times 10^{-5} \mathrm{M} \mathrm{pH} 4$
波長の短波長シフトが認められた。このことからも錯化 した銀イオンとポリチアザアルカン部分のアニリン窒素 との相互作用によって, ヒドラゾン部分の $\pi$ 電子共役 が変化することが示唆される.

\section{$3 \cdot 2$ ヒドラゾン誘導体の金属イオン抽出挙動 ${ }^{2425)}$}

ヒドラゾン誘導体をプロトン解離型イオノホアとして 使用した場合の金属イオンの溶媒抽出について検討し た。

$3 \cdot 2 \cdot 1$ 種々の金属イオンの抽出能第一にヒドラ ゾン誘導体による数種の金属イオン溶媒抽出実験につい て検討した。金属イオン濃度過剩の条件でヒドラゾン誘 導体 3 を含む 1,2-ジクロロエタン溶液により種々の金属 イオンの溶媒抽出を行った場合の有機相中の吸収スペク トルを Fig. 6 に示す。この図から銀イオンの抽出の場 合にその吸収スペクトルが著しく変化するが，ほかの金 属イオンではほとんど変化しないことが判明した. 次に

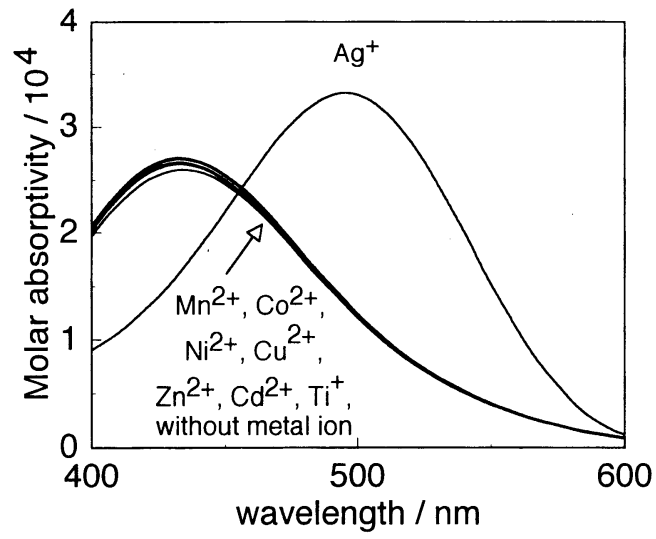

Fig. 6 Absorption spectra of the organic phase in the extraction of some metal ions from aqueous phase with 3

Table 3 The apparatus proton dissociation constants $\left(K_{\mathrm{a}}^{*}\right)$ and the spectral properties of silver ion complexes with hydrazone derivatives in 1, 4-dioxane-water solution

\begin{tabular}{cccc}
\hline Compound & $\mathrm{p} K_{\mathrm{a}}{ }^{* \mathrm{~b})}$ & $\varepsilon \mathrm{A}_{\mathrm{gHL}}{ }^{\mathrm{a})} / 10^{4}\left(\mathrm{at} \lambda_{\max } / \mathrm{nm}\right)$ & $\varepsilon_{\mathrm{AgL}}{ }^{\mathrm{a})} / 10^{4}(\mathrm{at} \lambda \mathrm{max} / \mathrm{nm})$ \\
\hline $\mathbf{1}^{\mathrm{c})}$ & 7.64 & $2.53(410)$ & $4.00(506)$ \\
$\mathbf{2}^{\mathrm{d})}$ & 7.94 & $2.73(428)$ & $3.95(508)$ \\
$\mathbf{3}^{\text {c) }}$ & 7.64 & $2.57(411)$ & $3.77(504)$ \\
$\mathbf{4}^{\text {c) }}$ & 7.57 & $2.40(402)$ & $3.80(501)$ \\
\hline
\end{tabular}

a) Errors for values of $\varepsilon$ were less than $\pm 300 \mathrm{~mol}^{-1} \mathrm{dm}^{3} \mathrm{~cm}^{-1}$, b) $\mathrm{p} K_{\mathrm{a}}^{*}=-\log K_{\mathrm{a}}^{*} ; K_{\mathrm{a}}^{*}=\left[\mathrm{H}^{+}\right][\mathrm{AgL}] /\left[\mathrm{AgHL}^{+}\right]$; erros for values of $\mathrm{p} K_{\mathrm{a}}{ }^{*}$ were within \pm 0.02 , c) In 1,4-dioxane-water $(48 / 52(\mathrm{v} / \mathrm{v}) \%)$, d) In 1,4-dioxane-water $(60 / 40(\mathrm{v} / \mathrm{v}) \%)$ 
Table 4 Extraction of matal ions by hydrazone derivatives $^{\text {a) }}$

\begin{tabular}{cccccc}
\hline \multirow{2}{*}{ Metal ion } & \multirow{2}{*}{$\begin{array}{l}\text { Classification } \\
\text { of metal ion }\end{array}$} & \multicolumn{5}{c}{ Extraction, \% } \\
\cline { 3 - 6 } & & $\mathbf{1}$ & $\mathbf{2}$ & $\mathbf{3}$ & $\mathbf{4}$ \\
\hline $\mathrm{Mn}^{2+}$ & $a b$ & 0 & 0 & 0 & 0 \\
$\mathrm{Co}^{2+}$ & $a b$ & 0 & 0 & 0 & 0 \\
$\mathrm{Ni}^{2+}$ & $a b$ & 0 & 0 & 0 & 0 \\
$\mathrm{Cu}^{2+}$ & $a b$ & 0 & 0 & 2 & 4 \\
$\mathrm{Zn}^{2+}$ & $a b$ & 0 & 0 & 1 & 2 \\
$\mathrm{Tl}^{+}$ & $a b$ & 0 & 0 & 4 & 3 \\
$\mathrm{Cd}^{2+}$ & $b$ & 0 & 0 & 0 & 0 \\
$\mathrm{Ag}^{+}$ & $b$ & 0 & 0 & 84 & 30 \\
\hline
\end{tabular}

a) Organic phase: [ligand] $=1.0 \times 10^{-4}$ in $1,2-$ dichloroethane; Aqueous phase: [metal ion] = $2.0 \times 10^{-5} \mathrm{M}, \mathrm{pH}=6$. b) Value were obtained from determination of the remaining metal ion concentration in the aqueous phase.

試薬濃度過剩の条件で原子吸光法によって金属イオン溶 媒抽出実験を行った場合の金属イオン抽出率の值を Table 4 に示す。一連のヒドラゾン誘導体のうち， 4 個 の硫黄原子を有するヒドラゾン誘導体 3，4 は銀イオン を選択的に抽出し，ほかの金属イオンはほとんど抽出し なかった。一方，2 個の硫黄原子を有するヒドラゾン誘 導体 1,2 はどの金属イオンも抽出しない結果となった. 前述のジオキサンー水混合溶液系における実駼結果か ら，ヒドラゾン誘導体 3，4 は銀イオンと選択的かつ定 量的に錯形成するために，溶媒抽出系においてもまた銀 イオンを選択的に抽出するものと考えられる。一方，ポ リチアザアルカン部分に 2 個しか硫黄原子を持たない ヒドラゾン誘導体 1，2 ではその金属イオン錯形成能が 低いために, 結果としてどの金属イオンも抽出しないも のと考えられる.

$3 \cdot 2 \cdot 2$ 銀イオンの溶媒抽出 次にヒドラゾン誘導 体による銀イオンの抽出挙動を詳細に検討した。 ヒドラ ゾン誘導体 3 による銀イオンの溶媒抽出に扔ける水相 の $\mathrm{pH}$ 変化と有機相中の吸収スペクトルとの関係を Fig. 7 に示す。遊離のヒドラゾン誘導体 3 は, $440 \mathrm{~nm}$ 付近 に吸収極大を持つが, $\mathrm{pH}$ の増加に伴う錯形成とともに 吸収極大が $500 \mathrm{~nm}$ 付近に移動する。この現象は Fig. 8 に示すように，イミノ基水素と銀イオンとの交換により 生じた中性錯体が，有機相へ抽出されることを示唆す る. 一連のヒドラゾン誘導体において，水相の $\mathrm{pH}$ 変化 と錯体の吸収極大波長（500 nm）におけるヒドラゾン 誘導体の見掛けのモル吸光係数との関係を Fig. 9 にプ ロットした。これより，すべてのヒドラゾン誘導体のう

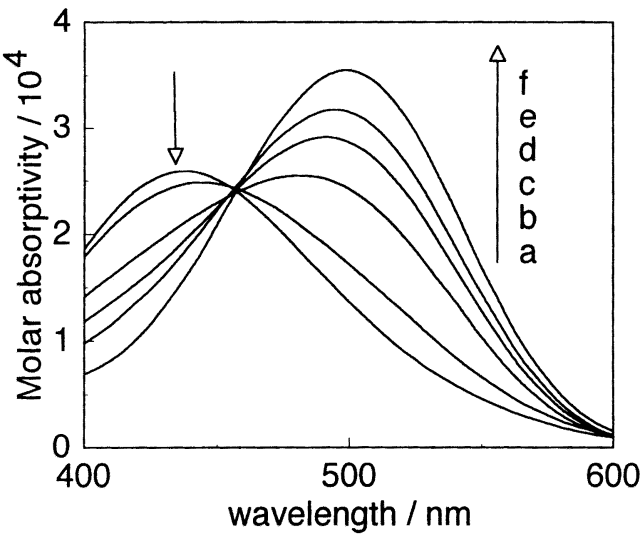

Fig. $7 \mathrm{pH}$ dependent spectral change of hydrazone 3 on silver ion extraction

[ligand] $=1 \times 10^{-5} \mathrm{M}$; [silver ion ] $=2 \times 10^{-4} \mathrm{M}$; $\mathrm{pH}=$ a) 3.58 , b) 4.31 , c) 5.13 , d) 5.69 , e) $6.08, \mathrm{f}$ ) 7.34

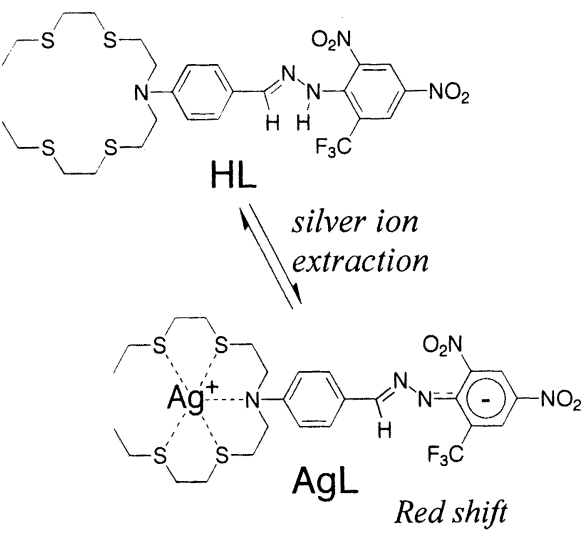

Fig. 8 Postulated structures of silver ion complex of hydrazone 3 extracted from aqueous phase into organic phase

ち，3 が最も低い $\mathrm{pH}$ から銀イオンを抽出し，4がこれ に次ぐ低い $\mathrm{pH}$ から抽出することが分かる，又，ヒドラ ゾン誘導体 1，2では錯形成部のポリチアザアルカン部 分の低い錯形成能のためか, 中性付近でも吸光度の変化 が見られず，更に弱塩基性領域においては銀イオン共存 下でヒドラゾン誘導体の分解と思われる吸光度の減少が 見られた。次に，ヒドラゾン誘導体 $3 ， 4$ により抽出さ れる銀イオン錯体の組成比を求めるために, 試薬濃度変 化に対する銀イオン分配比への影響について検討した。 


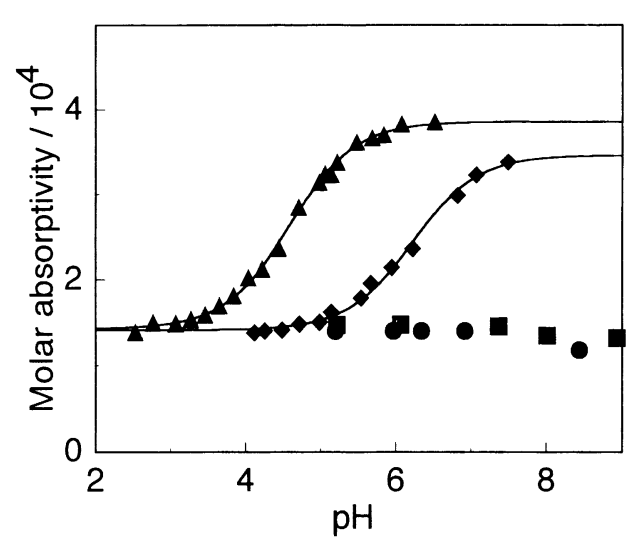

Fig. 9 Plots of molar absorptivity of the organic phase at $500 \mathrm{~nm} v s \mathrm{pH}$ of the aqueous phase on the extractions of silver ion with hydrazone derivatives

$1 ;(\square): 2 ;(\bigcirc): 3 ;(\Delta): 4 ;(\diamond)$ : Initial concentration: $\left[\right.$ ligand] $=1 \times 10^{-5} \mathrm{M}$

溶媒抽出において錯体は一般に試薬のプロトンが 1 個 解離して $\operatorname{AgL}(\mathrm{HL})_{m-1}$ の形で有機相へ抽出されると考え られる。すなわち, 分子内イオン対を形成した錯体 $\operatorname{AgL}$ に対して $m-1$ 個の試薬がプロトン解離しない形で 配位する場合を考慮する必要がある.この場合の銀イオ ン抽出平衡と抽出定数 $K_{\mathrm{ex}}$ 及び分配比 $D$ は次のように表 される.

$$
\begin{aligned}
& \mathrm{Ag}^{+}+m(\mathrm{HL})_{\mathrm{O}} \rightleftharpoons \mathrm{H}^{+}+\left(\mathrm{AgL}(\mathrm{HL})_{m-1}\right)_{\mathrm{O}} \\
& K_{\mathrm{ex}}=\frac{\left[\mathrm{H}^{+}\right]\left[\mathrm{AgL}(\mathrm{HL})_{m-1}\right]_{\mathrm{O}}}{\left[\mathrm{Ag}^{+}\right][\mathrm{HL}]_{\mathrm{O}}^{m}} D_{\mathrm{Ag}}=\frac{\Sigma\left[\mathrm{AgL}(\mathrm{HL})_{m-1}\right]_{\mathrm{O}}}{\left[\mathrm{Ag}^{+}\right]+\Sigma\left[\mathrm{AgL}(\mathrm{HL})_{m-1}\right]}
\end{aligned}
$$

しかし，水相中の銀イオン錯体の濃度は無視できる程低 いため，銀イオン分配比は次のように近似することがで きる。

$$
\log D_{\mathrm{Ag}}=\log K_{\mathrm{ex}}+m \log [\mathrm{HL}]_{\mathrm{O}}+\mathrm{pH}
$$

従って試薬濃度変化による銀イオンの分配比の変化を検 討することにより, 抽出錯体の組成比及び抽出定数を算 出することができる. この場合, ヒドラゾン誘導体 3 ではこう配 1 の直線を与えるが, ヒドラゾン誘導体 4 では試薬濃度の低い範囲では勾配 1 , 試薬濃度の高いと ころでは勾配 2 の直線を得た。すなわち, ヒドラゾン 誘導体 3 では銀イオン: 試薬 $=1: 1$ の錯体を形成する が, ヒドラゾン誘導体 4 ではヒドラゾン誘導体濃度の 増加に伴い, 銀イオン: 試薬 $=1: 1$ 錯体から銀イオン: 試薬 $=1: 2$ 錯体に組成が変化することを意味する.こ の銀イオン錯体の組成比を参考にして, 水相の $\mathrm{pH}$ 変化 に対する有機相の見掛けのモル吸光係数のプロットから 銀イオンの抽出定数を算出した. なお, ここで $2: 2$ や $3: 3$ 錯体の生成は見られなかった. それぞれのヒドラ ゾン誘導体による銀イオン抽出定数と抽出錯体のモル吸 光係数を Table 5 にまとめた. 得られた抽出定数は先 の試薬濃度変化に対する分配比の関係から得られた值と よく一致した.この表から本実験条件でヒドラゾン誘導 体 3 と 4 を比較すると, 銀イオン: 試薬 $=1: 1$ 錯体の 抽出定数からも非環状の 3 を用いたほうが銀イオンが 抽出されやすいことが分かる. 環状のヒドラゾン誘導体 4 の場合, その無置換体（N-フェニル $-4,7,10,13-$ テラ チア-1-アザシクロペンタデカン）の銀イオン錯体はひず んだ四面体構造を形成することが X 線結晶構造解析の 結果から得られている ${ }^{26)}$. このため銀イオンと錯形成す る際に構造的に自由度の高い非環状のほうが安定な立体 配座をとるため, より高い銀イオン抽出能を示すものと 考えられる。

$3 \cdot 3$ ヒドラゾン誘導体による銀イオンのプロトン駆 動型液膜輸送 ${ }^{15)}$

ヒドラゾン誘導体 3,4 は水相が中性付近で銀イオン と選択的に錯形成して有機相に抽出することを認めた.

Table 5 Extraction constants $\left(K_{\mathrm{ex}}\right)$ and molar absorptivities $(\varepsilon)$ of silver ion complexes with hydrazone derivatives

\begin{tabular}{cccccc}
\hline Compound & $\log K_{\text {ex } 11}{ }^{\mathrm{a})}$ & $\log K_{\mathrm{ex} 12}{ }^{\mathrm{b})}$ & $\begin{array}{c}\varepsilon_{\mathrm{HL}} / 10^{4} \\
\left(\lambda_{\max } / \mathrm{nm}\right)\end{array}$ & $\varepsilon_{\mathrm{AgL}}{ }^{\mathrm{c}} / 10^{4}$ & $\varepsilon_{\mathrm{Ag}(\mathrm{HL}) \mathrm{L}}{ }^{\mathrm{c})} / 10^{4}$ \\
\hline $\mathbf{1}$ & - & - & - & - & - \\
$\mathbf{3}$ & - & - & - & - & - \\
$\mathbf{4}$ & -0.92 & - & $2.69(439)$ & 3.87 & 4.98 \\
\hline
\end{tabular}

a) $K_{\text {ex } 11}=\left[\mathrm{H}^{+}\right][\mathrm{AgL}] \mathrm{o} /\left[\mathrm{Ag}^{+}\right][\mathrm{HL}] \mathrm{o}$, b) $K_{\text {ex } 12}=\left[\mathrm{H}^{+}\right][\mathrm{Ag}(\mathrm{HL}) \mathrm{L}] \mathrm{o} /\left[\mathrm{Ag}^{+}\right][\mathrm{HL}] \mathrm{o}^{2}$, c) at $500 \mathrm{~nm}$. 


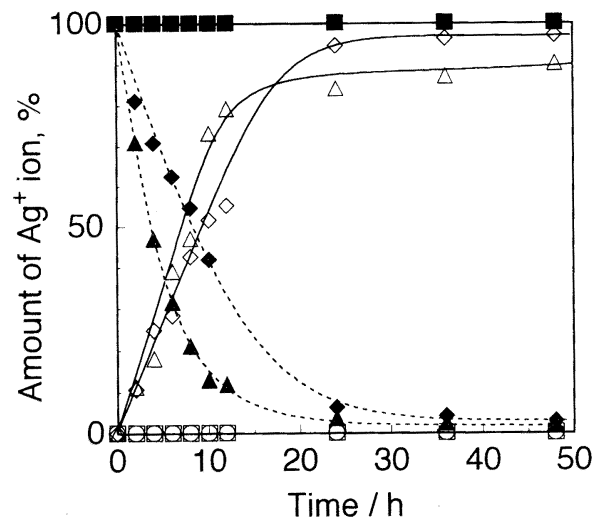

Fig. 10 Transport behavior of silver ion through the liquid membranes containing hydrazone derivatives 1 4: dashed lines, source phase; solid lines, receiving phase $\square, \square$, membrane of $1 ; 0, \bigcirc$, membrane of $2 ; \boldsymbol{\Delta}, \triangle$, membrane of $3 ; \diamond, \diamond$, membrane of 4. Source phase, [Silver sulfate] $=1.25 \times$ $10^{-4} \mathrm{M}, \mathrm{pH} 6,15 \mathrm{ml}$; Membrane phase, [ligand] = $2.5 \times 10^{-4} \mathrm{M}$ in 1,2-dichloroethane, $15 \mathrm{ml}$; Receiving phase, $0.05 \mathrm{M} \mathrm{H}_{2} \mathrm{SO}_{4}, 15 \mathrm{ml}$

そこでこれらのヒドラゾン誘導体をプロトン解離型キャ リヤーとして使用した場合 ${ }^{12) 2728)}$ の銀イオンの液膜輸送 について検討した.

\section{$3 \cdot 3 \cdot 1$ ヒドラゾンを含む液膜の銀イオン輸送挙動}

それぞれのヒドラゾン誘導体を含む液膜による銀イオン 輸送実験を行った場合の輸送時間に対する両水相の銀イ オン濃度変化を Fig. 10 に示す.なお供給相としてキャ リヤーと同濃度の銀イオンを含み, $\mathrm{pH}$ を 6 に調節した 水溶液, 受容相として $0.05 \mathrm{M}$ 硫酸水溶液を使用した. 又, どのヒドラゾン誘導体も水相への漏れは見られなか った。この図から，ヒドラゾン誘導体 3，4 の液膜を用 いた場合，実験開始してからそれぞれ 8 時間後と 10 時 間後に供給相と受容相中の銀イオン濃度が逆転すること から，効率良くプロトン駆動型輸送が行われたことが分 かる，例としてヒドラゾン誘導体 3 による銀イオン輸 送の予想される機構を Fig. 11 に示す.このようにプロ トン駆動型の銀イオン輸送では, 供給相一液膜界面で銀 イオンを抽出したキャリヤーは受容相液膜界面で陰イオ ン性のヒドラゾン部分がプロトン化されて, その対陽イ オンとして存在する銀イオンの受容相への放出が促進さ れる. ヒドラゾン誘導体 3 は輸送開始して約 12 時間後 までは一定の流束で銀イオンを輸送するが, 24 時間後 には銀イオンを $100 \%$ 輸送せずにほとんど停止する. これに対してヒドラゾン誘導体 4 はヒドラゾン誘導体 3

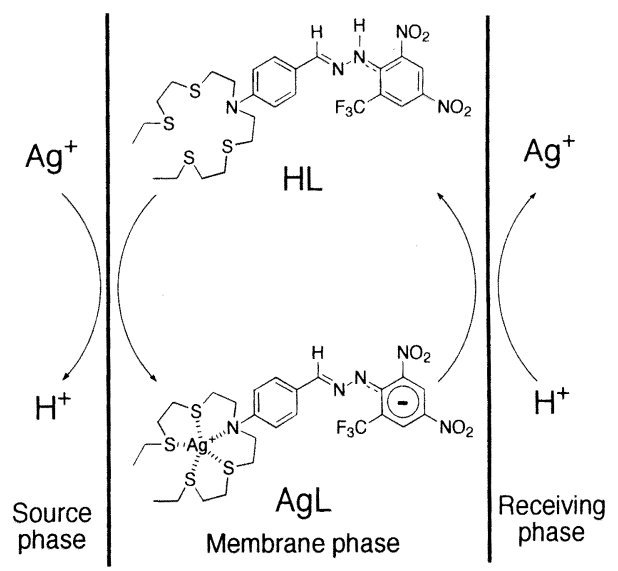

Fig. 11 Postulated mechanism of proton-driven silver ion transport through liquid membrane containing 3

より銀イオンの初期流束は小さいが, 輸送開始 2 日後 に供給相中の銀イオンをほほ 100\% 輸送した.ヒドラ ゾン誘導体 1，2 はどちらも銀イオンを輸送しなかった. これらのヒドラゾン誘導体は溶媒抽出においても銀イオ ンを有機相へ抽出しないことから, 輸送実験でも液膜相 へ銀イオンを取り达まず，輸送が行われないものと思わ れる。

$3 \cdot 3 \cdot 2$ ヒドラゾン誘導体 3 を含む液膜による銀イオ ン輸送に及ぼす受容相中の $\mathrm{pH}$ の影響最も迅速に銀 イオンを輸送するヒドラゾン誘導体 3 を用いた場合の, 受容相中のプロトン濃度が銀イオン輸送挙動に及ぼす影 響を検討した，受容相として，1）1 M 硫酸水溶液，2） $0.05 \mathrm{M}$ 硫酸水溶液, 3) 供給相と同じ $\mathrm{pH}$ 条件で銀イオ ンを含まない水溶液，の 3 種類を用いて銀イオンの液 膜輸送を行った．輸送時間に対する両水相の銀イオン濃 度変化を Fig. 12 に示す. 銀イオン輸送量は 2) の条件 で最も良く，2）>3）>1）の条件の順で低下した。受容 相中の $\mathrm{pH}$ が供給相と同じ 3）の条件では, 液膜に銀イ オンが取り込まれても両水相のプロトン濃度勾配がない ために，プロトン駆動型の銀イオン輸送は起こらな い.そのため, この銀イオン輸送過程は受動輸送となる ために，両水相中の銀イオン濃度が等しくなったところ で銀イオン輸送は停止すると考えられる. 受容相のプロ トン濃度が 2）よりも高い 1）の条件では，その高いプ ロトン濃度にかかわらず，ほとんど銀イオンを輸送しな かった.これは錯形成部であるポリチアザアルカン鎖の アニリン窒素原子がプロトン付加して銀イオンと相互作 


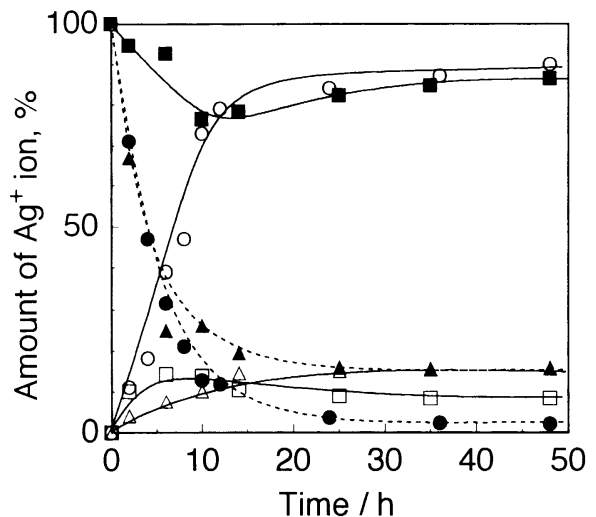

Fig. 12 Effect of the acidity of the receiving phase on the transport behavior of silver ion through the liquid membrane containing 3 : dashed lines, source phase; solid lines, receiving phase

Source phase, [silver sulfate] $=1.25 \times 10^{-4} \mathrm{M}, \mathrm{pH} 6$, $15 \mathrm{ml}$; Membrane phase, [ligand] $=2.5 \times 10^{-4} \mathrm{M}$ in 1,2-dichloroethane, $15 \mathrm{ml}$; Receiving phase, 1) $\mathbf{\square}$, $\square, 1 \mathrm{M} \mathrm{H}_{2} \mathrm{SO}_{4}$; 2) $\bigcirc, 0.05 \mathrm{M} \mathrm{H}_{2} \mathrm{SO}_{4}$; 3) $\boldsymbol{\Delta}, \Delta$, $\mathrm{pH} 6,15 \mathrm{ml}$

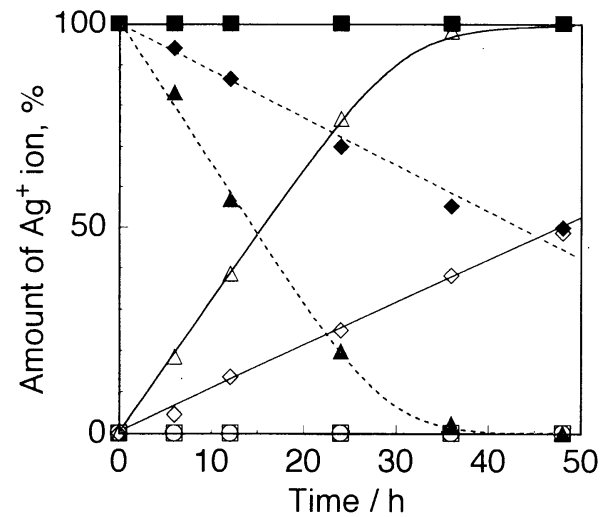

Fig. 13 Transport behavior of silver ion through the liquid membranes containing hydrazone derivatives 1 4: dashed lines, source phase; solid lines, receiving phase $\square, \square$, mimbrane of $\mathbf{1} ; \mathbf{0}, \bigcirc$, membrane of $2 ; \boldsymbol{\Delta}, \triangle$, membrane of $3 ; \diamond, \diamond$, membrane of 4 . Source phase, [silver sulfate] $=2.5 \times$ $10^{-3} \mathrm{M}, \mathrm{pH} 6$ adjusted using $0.2 \mathrm{M}$ citric acid-KOH buffer, $15 \mathrm{ml}$; Membrane phase, [ligand] $=2.5 \times$ $10^{-4} \mathrm{M}$ in 1,2-dichloroethane, $15 \mathrm{ml}$; Receiving phase, $0.05 \mathrm{M} \mathrm{H}_{2} \mathrm{SO}_{4}, 15 \mathrm{ml}$

Table 6 Competitive transport of metal ions through liquid membrane of $\mathbf{3}$ and $\mathbf{4}$

\begin{tabular}{|c|c|c|c|c|}
\hline \multirow{3}{*}{ Metal ions } & \multicolumn{4}{|c|}{ Amount of metal ions after 48 h, $\%$} \\
\hline & \multicolumn{2}{|c|}{3} & \multicolumn{2}{|c|}{4} \\
\hline & Source phase & Receiving phase & Source phase & Receiving phase \\
\hline $\mathrm{Fe}^{3+}$ & 100 & 0 & 100 & 0 \\
\hline $\mathrm{Co}^{2+}$ & 100 & 0 & 100 & 0 \\
\hline $\mathrm{Ni}^{2+}$ & 100 & 0 & 100 & 0 \\
\hline $\mathrm{Cu}^{2+}$ & 100 & 0 & 100 & 0 \\
\hline $\mathrm{Zn}^{2+}$ & 100 & 0 & 100 & 0 \\
\hline $\mathrm{Cd}^{2+}$ & 100 & 0 & 100 & 0 \\
\hline $\mathrm{Ag}^{+}$ & 0 & 100 & 49 & 50 \\
\hline $\mathrm{Hg}^{2+}$ & 100 & 0 & 100 & 0 \\
\hline
\end{tabular}

Source phase: $\left[\mathrm{Fe}^{3+}\right],\left[\mathrm{Co}^{2+}\right],\left[\mathrm{Ni}^{2+}\right],\left[\mathrm{Cu}^{2+}\right],\left[\mathrm{Zn}^{2+}\right],\left[\mathrm{Cd}^{2+}\right],\left[\mathrm{Hg}^{2+}\right]$ and $\left[\mathrm{Ag}^{+}\right]=5.0 \times 10^{-3} \mathrm{M}$, pH $=5.9$ adjusted using $0.2 \mathrm{M}$ citric acid-KOH buffer, $15 \mathrm{ml}$. Membrane phase: [ligand] $=2.5 \times 10^{-4} \mathrm{M}$ in $15 \mathrm{ml} 1,2-$ dichloroethane. Receiving phase: $\left[\mathrm{H}_{2} \mathrm{SO}_{4}\right]=0.05 \mathrm{M}, 15 \mathrm{ml}$

用しなくなり，銀イオンを輸送しなくなるためと考えら れる.

$3 \cdot 3 \cdot 3$ 数種の金属イオン共存下での銀イオンの液膜 輸送次に, 液膜中のヒドラゾン誘導体濃度に対して 大過剩の銀イオンを含む供給相を使用した場合の，銀イ オン輸送実験を行った場合の輸送時間に対する両水相の 銀イオン濃度変化を Fig. 13 に示す. 供給相として 0.2 M クエン酸緩衝液により $\mathrm{pH}$ を 6 に調節した水溶液,
受容相として $0.05 \mathrm{M}$ 硫酸水溶液を使用した。この図か ら, 銀イオン輸送量はヒドラゾン誘導体 3 の場合に最 も多く, 3>4》1, 2 の順に低下することが分かる. 又, ヒドラゾン誘導体 3，4 の液膜を用いた場合，実験開始 してからそれぞれ 15 時間後と 48 時間後に供給相と受 容相中の銀イオン濃度が逆転することから, 効率良くプ ロトン駆動型輸送が行われたことが分かる．特にヒドラ ゾン誘導体 3 は, 輸送開始 40 時間後に完全に銀イオン 
を輸送することを認めた。一方，ヒドラゾン誘導体 1 , 2 はどちらも銀イオンを輸送しなかった．更に銀イオン 輸送能を示したヒドラゾン誘導体 3，4 を用いて数種の 金属イオン共存下での銀イオンの選択的液膜輸送を試み た．ヒドラゾン誘導体 3，4 を含む液膜を用いて，数種 の金属イオンをそれぞれ $5 \times 10^{-3} \mathrm{M}$ を共存させた水溶 液を供給相とする競争輸送実験を行った場合の, 輸送開 始 2 日後の結果を Table 6 に示す。この表から，ヒド ラゾン誘導体 3 と 4 を用いた場合に供給相中の銀イオ ンをそれぞれ $100 \%$ と $48 \%$ 受容相へ輸送して，どちら のヒドラゾン誘導体も他の金属イオンを全く輸送しない ことが分かる．特に，ヒドラゾン誘導体 3 は銀イオン を迅速かつ選択的に輸送・分離することを認めた。

$$
4 \text { 結 語 }
$$

本稿では新規な有機試薬の開発を目的として，プロト ン解離型発色団であるヒドラゾン部分を持つポリチアザ アルカン誘導体を合成し，金属イオンのセンシングと液 膜分離について検討した。ジオキサンー水混合溶液系及 び溶媒抽出系どちらの場合においても，ヒドラゾン誘導 体 3，4 はいずれも銀イオンと選択的に錯形成すること を認めた．特に高い銀イオン抽出能を示したヒドラゾン 誘導体 3 では, 銀イオン錯体の生成に伴う吸収スペク トルの変化を利用した銀イオンの選択的な分光光度定量 への応用が期待される．又，ヒドラゾン誘導体をプロト ン解離型キャリヤーとする銀イオンのプロトン駆動型液 膜輸送において，ヒドラゾン誘導体 3,4 の液膜が銀イ オンを選択的に輸送し, 特にヒドラゾン誘導体 3 は迅 速に銀イオンを輸送することから，銀イオンの分離郕と して有用であることが判明した。

このような機能性を示す化合物の色素化修飾は，選択 的な比色試薬の開発ばかりでなく，その認識の有無を光 の変化に変換する分子素子への応用という点でも重要で ある。これからも高付加価值のある機能性化合物の開発 が期待される.

本研究を行うに当たり，御指導を承りました先生方に深 く感謝の意を表します，更に，実験に協力していただきま した学部生諸君に深く御礼申し上げます。最後に，日本分 析化学会中部支部創立 40 周年記念論文として発表の機会を 与えてくださいました関係者の方々に深く感謝致します。

\section{文献}

1) C. J. Pedersen: Angew. Chem., Int. Ed. Engl., 27,
1021 (1988).

2) J. M. Lehn: Angew. Chem., Int. Ed. Engl., 27, 89 (1988).

3) 平岡道夫: “クラウン化合物”, (1978), (講談社).

4) R. M. Izatt, J. S. Bradshaw, S. A. Nielsen, J. D. Lamb, J. J. Christensen, D. Sen: Chem. Rev., 85, 271 (1985).

5) R. M. Izatt, K. Pawlak, J. S. Bradshaw: Chem. Rev, 91, 1721 (1991).

6) R. M. Izatt, J. S. Bradshaw, K. Pawlak, R. L. Bruening, B. J. Tarbet: Chem. Rev., 92, 1261 (1992).

7) E. Kimura: Tetrahedron, 48, 6175 (1992).

8) S. R. Cooper: Acc. Chem. Res., 21, 141 (1988).

9) H. Nakamura, M. Takagi, K. Ueno: Anal. Chem., 52, 1668 (1980).

10) G. E. Pacey, Y. P. Wu, B. P. Bubnis: Analyst (London), 106, 636 (1981).

11) H. Sakamoto, H. Goto, M. Yokoshima, M. Dobashi, J. Ishikawa, K. Doi, M. Otomo: Bull. Chem. Soc. Jpn., 66, 2907 (1993).

12) H. Sakamoto, K. Kimura, T. Shono: Anal. Chem., 59, 1513 (1987).

13) H. Sakamoto, J. Ishikawa, M. Otomo: Bull. Chem. Soc. Jpn., 68, 2831 (1995).

14) J. Ishikawa, H. Sakamoto, T. Mizuno, M. Otomo: Bull. Chem. Soc. Jpn., 68, 3071 (1995).

15) J. Ishikawa, H. Sakamoto, M. Otomo: Analyst (London), 122, 1383 (1997).

16) J. P. Dix, F. Vögtle: Chem. Ber., 113, 457 (1980).

17) J. P. Dix, F. Vögtle: Chem. Ber., 114, 638 (1981).

18) H.-G. Löhr, Fritz Vögtle: Acc. Chem. Res., 18, 65 (1985).

19) J. Bourson, B. Valeur: J. Phys. Chem., 93, 3871 (1989).

20) S. F.-Forgues, M.-T. L. Bris, J.P. Guette, B. Valeur: J. Phys. Chem., 92, 6233 (1988).

21) K. Saito, Y. Masuda, E. Sekido: Anal. Chim. Acta, 151, 447 (1983)

22) E. Sekido, K. Saito, Y. Naganuma, H. Kumazaki: Anal. Sci., 1, 363 (1985).

23) E. Sekido, H. Kawahara, K. Tsuji: Bull. Chem. Soc. Jpn., 61, 1587 (1988).

24) J. Ishikawa, H. Sakamoto, T. Mizuno, K. Doi, M. Otomo: Analyst (London), 123, 201 (1998).

25) H. Sakamoto, J. Ishikawa, T. Mizuno, K. Doi, M. Otomo: Chem. Lett., 1993, 609.

26) J. Ishikawa, H. Sakamoto, M. Nakamura, K. Doi, H. Wada: J. Chem. Soc., Dalton Trans., accept.

27) E. Kimura, C. A. Dalimunte, A. Yamasita, R. Machida: J. Chem. Soc., Chem. Commun., 1985, 1040.

28) K. Hiratani, T. Takahashi, H. Sugiura, K. Kasuga, K. Fujiwara, K. Hayashita, R. A. Bartsch: Anal. Chem., 69, 3002 (1997). 


\section{要 旨}

プロトン解離型発色団としてヒドラゾン部分を有するポリチアザアルカン誘導体による金属イオン錯 形成平衡，溶媒抽出並びに液膜輸送について検討した．第一にジオキサンー水混合溶液系では，いずれ の化合物も類似した酸解離平衡と高い銀イオン錯形成能を示し, 銀イオン錯形成により吸収スペクトル が大きく短波長シフトした．銀イオン錯体の安定度は錯形成部であるポリチアザアルカン鎖の硫黄原子 の数に依存することを認めた。第二に金属イオンの溶媒抽出を行ったところ，硫黄原子を 4 個持つ誘導 体に扔いて高い銀イオン選択性を示し, 銀イオン抽出により有機相中の吸収スペクトルが長波長シフト した。銀イオン錯体はポリチアザアルカン部分が非環状のもののほうがより低い $\mathrm{pH}$ 領域から抽出され る.第三に液膜輸送のキャリヤーとして使用したところ，ポリチアザアルカン鎖に硫黄原子を 4 個持つ ものがプロトン駆動型の選択的な銀イオン輸送能を示した。特に非環状のポリチアザアルカン鎖を持つ ヒドラゾン誘導体 3 は高い銀イオン輸送能を示した. 